\title{
In Hot Water: The ecological politics of development
}

\section{WENDY HARCOURT}

In preparation for this volume I found myself in New York for two days in November just before the United Nations Climate Change Conference to be held in Bali, Indonesia 3-14 December 2007. The occasion was a high-level United Nations Expert Group Meeting on 'Strengthening international cooperation for development to address the climate change challenge' organized jointly by the Committee for Development Policy of UN-DESA, the Stockholm Environment Institute and the SID journal Development. It was studded with an impressive number of experts and high-level UN leaders. Tariq Banuri who organized the meeting crafted a series of strategic moments, bringing together thoughtful and impassioned people from Europe, South East and South Asia, USA and The Caribbean. They clearly impressed the array of ambassadors listening to the conclusions at the end of the meeting. The final session was attended by the President of ECOSOC, the Chairman of the Group of 77 and Ambassadors from Algeria, Iceland, Brazil, Japan, Pakistan and Sweden.

It was a colourful group. There was Hunter Lovins, of Natural Capital Solutions in her cowgirl hat giving a fast-talking, wise-cracking performance in favour of business leading the way that was timed to perfection; Robert Ackerman of Tufts University, immaculate in his grey suit, giving a PowerPoint presentation that defied anyone to claim economics was boring. From his take on the Stern Report to his funny but searing comments on the startling near pornographic images of the Diesel clothing company featuring a climate change world as their backdrop, he was entertainment itself. Then there was Adil Najam from the Fletcher School with his sliding narratives conjured out of a 1,000 pictures that summarized core concerns of the meeting in breath taking sophistication. Interspersed were thoughtful comments from civil society intellectuals taking up strong political and ecological critiques. Larry Lohmann from Corner House and Barbara Hariss-White from Oxford University argued brilliantly with their understated anger, unpacking the politics of policy in insightful ways. Renowned civil society player on the UN scene, Martin Khor from Third World Network contributed sporadically, always as if he were juggling a thousand other political encounters from his laptop. His strategic outbursts and tough, measured intervention continually focused the meeting on the inequities of global development from the perspective of the South. And 
always in the background there was the elegant organizer Tariq Banuri now at the Stockholm Environment Institute bringing the debates together, introducing the right political player at the right time, knowing to give Jomo Sundaram, now Assistant Secretary-General of UN-DESA and well-known political economist in his own right, the space and time to comment.

The strategic aim of the meeting was to bring development issues to the attention of Governments due to attend the Climate Change Conference in Bali. The substantive aim was to bring together climate change experts together with environmental economists and civil society activists to look at how to apply a sustainable development perspective to climate. Sitting in the basement of the UN enjoying the talks, the conversations and the knowledge gathered in the room, even smiling at the usual spats about whether there were enough women participating (there were not), and that gender was mentioned and respected, I had this uneasy feeling that I had been here before. More than that, even if climate change was now headline news nearly every day, what was exactly new in all of this we were discussing? I recall other such meetings leading up to the UN Conference on Environment and Development held in Rio de Janeiro 1992. There Tariq Banuri and no doubt most of us around the table were 'greening economics' and producing copious numbers to show scientifically that unfettered economic growth was bad for the environment and for the very poor. Ecologists were speaking about common agendas and different responsibilities then. The South was rallying against the North, in fact Martin Khor was already there, skilful as ever, advising his Government on how to read the documents. I and others were trying from the margins to bring in women's role and agency into the debate. Governments were being pressed to agreements and technological changes and were promising and not living up to anything. Doom and gloom scenarios abounded alongside neat case studies that on the ground showed what a difference sustainable, community engaged, culturally aware development could make. There were of course far less PowerPoint presentations, much send whole documents with a push of a button. And the public was not treated to quite the same show.

I remember returning home from Rio with a huge sense of excitement that I had met the world, and change was going to happen. Not only was there Agenda 21 but there had been all those people thronging together in Flamingo Park in the biggest (at that time) international civil society meeting ever. It seemed that civil society had arrived as the 'third' actor in development alongside business and government. But when I spoke about my trip, not many of my friends had even heard of the meeting, let alone understood what UNCED meant or why lots of people meeting in a public park in Rio had any significance at all.

But these days Climate Change is in capital letters, Kyoto Protocol and the preparations for Bali are way up on the agenda. The first promise of the newly elected Australian Prime Minister Kevin Rudd was that Australia would sign the Kyoto Protocol and he would go to Bali. My copy of the Independent on Sunday, picked off the plane on my way to New York reporting UN Secretary General Ban Ki-Moon launch of the report of the Intergovernmental Panel on Climate Change (IPCC) which shared the Nobel Peace Prize with Al Gore screamed out 'A World Dying. But can we unite to save it?' What is to be done? asks the editorial comment as countries bound to Kyoto fail to meet their targets. Could Bali which discusses targets and mechanisms really make the difference? Is the battle to avert ecological disaster now beginning in earnest? (Independent on Sunday, 18 November 2007: 8, 9 and 39)

Given the same space on the same page of the editorial of the Independent was an article headed 'Angelina Jolie - she's the antidote to despair'. Angelina Jolie who I last saw as the swashbuckling unbelievably sexy killer Mrs Smith on film, is in real life according to journalist Sandra Sands the 'Amartya Sen of actresses', writing for The Economist on Darfur, attending the World Economic Forum at Davos. Apparently at Davos she is also accompanied by Sharon Stone who is dazzlingly described as 'something of a Noam Chomsky in her own right' (Sands, 2007). Sharon Stone? 
The face that shines out from all those Lancome ads defying age on bill board and screen?

Reflecting on the power of the media, and apparently the power of these glamorous actresses I felt even more uneasy about the meeting in the UN basement. What were we doing in New York preparing the battleground with marvelous presentations and slides rehearsing our jokes on cue? Our confessions of thwarted civil society activists? Are we all secretly wanting to be politician turned Nobel Peace Prize winner film star Al Gore?

Political Ecology the subject of this volume devoted to environment and development ${ }^{1}$ needs to understand not only the figures, the science and technology but also the culture and politics that surrounds development policy and practice. It seems that we are in an era where the best way to get things done is to mix stars and public policy, media and gloss. It seems to go with private and public partnerships. Academic facts and knowledge packaged attractively to reach the public, make them listen, put the pressure on politicians to act. As Financial Times columnist Gideon Rachman points out the Irish rock star Bono is now synonymous with African poverty. His hobnobbing with the world's leaders helped to bring about debt cancellation of US\$ 70 billion for African countries and raised money for antimalarial bed-nets and drugs to combat HIV (Rachman, 2007). I share Rachman's unease about unelected celebrities intimidating politicians while gushing about their corporate partners support to end poverty. Bono writes in a recent edition of Vanity Fair he guest edited that 'American Express, Apple, Emporio Armani ... are heroic' (http:// www.vanityfair.com/politics/features/).

But if they get things done who are we to question the stars' apparent role in making the world a better place? What is wrong with their glitzy highly publicized campaigns for Africa which for the most part raise a lot of money (let us put to one side the equally publicized fashion to adopt cute third-world children)? Do they not succeed where years of expensive UN negotiations have failed? What is the difference between their take on development and poverty and the environmentalists negotiating with their governments in Bali creating spaces such as 'Solidarity Village for A Cool Planet'?

The difference is manifold. For the stars the answer is money. Nicole Kidman (no less) just sent me an e-mail (via the listservs in UNIFEM) to ask me to donate money to end violence against women. As someone who has worked to end violence against women since Ms Kidman was ten years old I know the answer is not money. What is critical now is to change economic priorities and the culture of how we understand development. Money for aid and debt relief is important but is only part of the solution. The agenda is much broader. We are talking world governance, change in markets and trade regimes, challenging scientific arrogance and nuclear and military powers.

The difficulties we are facing are essentially political. What I heard at the UN expert meeting is that the knowledge is there, but the politics of how to ensure common agendas with differential responsibilities is not. We have the agendas, what we do not have is the political support of the heavy weight governments, US, Europe, India and China and multinational corporations. The issue is far from cut and dried. We need to have multiple strategies. No doubt entertaining PowerPoints help and money for antimalarial nets are crucial. But it is how and where we make the changes that count. For example, do we engage or not with transnational corporations, how do we change the current governance structures and how can we best engage broad population participation. These are complex political questions to be hammered out in the cabinets, in board rooms, in the UN, in the streets, in dumps and urban slums, valleys and dry river beds, in print, on the screen, on blogs and no doubt on YouTube. We cannot afford to translate complex issues into simple sound bites. There will be no real change if we fail to be rigorously honest about the vastly different contributions to cultures and politic economies made by Amartya Sen and Angelina Jolie, by Bill Gates and Ban Ki-Moon. We are living in a world that rewards Al Gore with the Nobel Peace Prize alongside the IPCC. Most people will remember the prize went to Al Gore. But critical public engagement in the serious and important work of the IPCC is going to make the difference. 


\section{Development 51(1): Editorial}

\section{Note}

1 Volume 51 will feature four issues covering 'Water for People, 'Gender and Fisheries, 'Climate Change and Development', and 'The Future of Agriculture'. We also take the occasion to launch a new cover for Development designed by the publishers Palgrave Macmillan in consultation with the editorial team reflecting the overall theme of the volume. We hope the readers like it.

\section{References}

Independent on Sunday (2007) 'A World Dying. But Can we Unite to Save It?', 18 November 2007, pp. 8-9.

Independent on Sunday (2007) 'Editorial Opinion. A Global Shift on Climate Change', 18 November 2007, p. 39.

Rachman, Gideon (2007) 'The Aid Crusade and Bono's Brigade', FT.com Financial Times, 29 October.

Sands, Sandra (2007) 'Angelina Jolie - She's the Antidote to Despair', Independent on Sunday, 18 November, p. 39. 